\title{
Glass Formulation Development and Testing for the Vitrification of Oak Ridge Tank Waste
}

by

M. K. Andrews

Westinghouse Savannah River Company

Savannah River Site

Aiken, South Carolina 29808

P. J. Workman

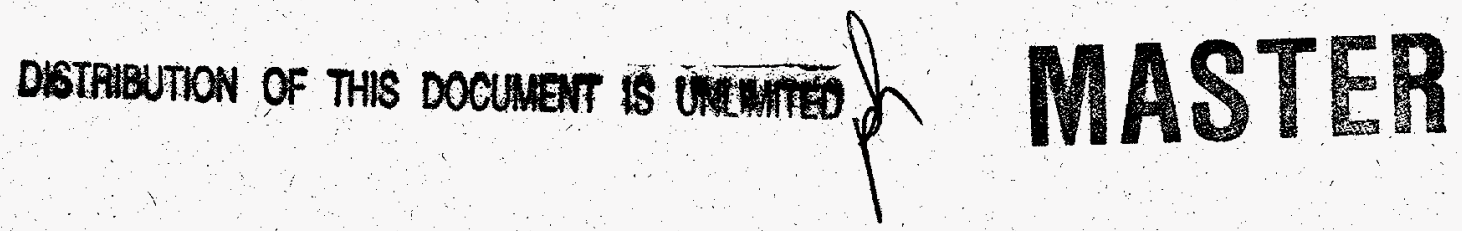

A document prepared for MIXED WASTE SYMPOSIUM at Baltimore, MD, USA from 8/17/97 - 8/21/97.

\section{DOE Contract No. DE-AC09-89SR18035 \& DE-AC09-96SR18500}

This paper was prepared in connection with work done under the above contract number with the U.S. Department of Energy. By acceptanice of this paper, the publisher and/or recipient acknowledges the $U, S$. Government's right to retain a nonexclusive, royalty-free license in and to any copyright covering this paper, along with the right to reproduce and to authorize others to reproduce all or part of the copyrighted paper. 


\section{DISCLAMMER}

This report was prepared as an account of work sponsored by an agency of the United States Government. Neither the United States Government nor any agency thereof, nor any of their employees, makes any warranty, express or implied, or assumes any legal liability or -responsibility for the accuracy, completeness, or usefulness of any information, apparatus, product, or process disclosed, or represents that its use would not infringe privately owned rights. Reference herein to any specific commercial product, process, or service by trade name, trademark, manufacturer, or otherwise does not necessarily constitute or imply its endorsement, recommendation, or favoring by the United States Government or any agency thereof.: The views and opinions of authors expressed herein do not necessarily state or reflect those of the United States Govemment or any agency thereof.

This report has been reproduced directly from the best available copy.

Available to DOE and DOE contractors from the Office of Scientific and Technical Infomation, P.O. Box 62, Oak Ridge, TN 37831; prices available from (615) 57.6-8401.

Available to the public from the National Technical-Information Service, U.S. Department of Commerce, 5285 Port Royal Road, Springfield, VA 22161. 


\section{DISCLAIMER}

Portions of this document may be illegible electronic image products. Images are produced from the best available original document. 
WSRC-MS-97--60051

\title{
GLASS FORMULATION DEVELOPMENT AND TESTING FOR THE VITRIFICATION OF OAK RIDGE TANK WASTE
}

\author{
Mary K. Andrews and Phyllis J. Workman \\ Westinghouse Savannah River Company \\ Savannah River Technology Center \\ Aiken, SC 29808
}

Tele: (803) 725-5253

Fax: (803) 725-4704

A paper proposed for presentation and publication in the Proceedings of the Fourth Biennial Mixed Waste Symposium, Baltimore, MD, August 17-21, 1997

This report was prepared in connection with work done under Contract No. DE-AC09-89SR18035 with the U.S. Department of Energy. By acceptance of this report, the publisher and/or recipient acknowledges the U.S.

Government's right to retain a nonexclusive, royalty-free license in and to any copyright covering this report, along with the right to reproduce and to authorize others to reproduce all or part of the copyrighted report. 
WSRC-MS-97-0051

\title{
Glass Formulation Development and Testing for the Vitrification of Oak Ridge Tank Waste
}

\author{
Mary K. Andrews and Phyllis J. Workman \\ Westinghouse Savannah River Company \\ Savannah River Technology Center \\ Aiken, SC 29808
}

\begin{abstract}
As part of a joint project between the Oak Ridge National Laboratory (ORNL) and the Savannah River Technology Center (SRTC), radioactive waste from four different ORNL tank farms will be immobilized. This work, which is funded by the DOE Office of Science and Technology, is designed to create a direct comparison between grouting and vitrification technologies. SRTC efforts have been focused on developing and testing glass formulations for the vitrification of the tank wastes.

The radioactive waste is from four different ORNL tank farms: Melton Valley Storage Tanks (MVST), Bethel Valley Evaporator Service Tanks (BVEST), Gunite and Associated Tanks (GAAT), and Old Hydrofracture Tanks (OHF). The sludges in these tanks contain transuranic radionuclides at levels which will make the glass waste form (at reasonable waste loadings) TRU.

Glass is an acceptable waste form because of its ability to accept a wide variety of components into its network structure. This is important since the waste varies significantly from tank to tank and from tank farm to tank farm. Therefore, glass formulation efforts have centered on developing a formulation that is robust enough to handle large fluctuations in waste composition. Crucible studies have been performed with simulated GAAT, MVST and BVEST sludges. The results of these tests indicate that high waste loadings can be obtained in the glass to significantly reduce the waste volume. This paper will present the results of the glass formulation efforts.
\end{abstract}

\section{INTRODUCTION}

The current strategy for immobilization and disposal of Oak Ridge (OR) tank wastes is based on privatization. The strategy is predicated on the ability of private vendors to reliably immobilize the waste into forms suitable for disposal at either the Nevada Test Site (NTS) or the Waste Isolation Pilot Plant (WIPP). It is anticipated that vendors are most likely to propose either grout or glass forms for treatment of the Melton Valley Storage Tank (MVST) waste. Prior to treatment of MVST waste, OR will add additional wastes to the MVST from three other OR tank farms: Bethel Valley Evaporator Service Tanks (BVEST), Gunite and Associated Tanks (GAAT) and Old Hydrofracture Tanks (OHF). 
Through the Tank Focus Area (TFA), SRTC is collaborating with the Oak Ridge National Laboratory (ORNL) in the immobilization of radioactive waste from the four OR tank farms. This work, which is funded by the DOE Office of Science and Technology, is designed to create a direct comparison between grouting and vitrification technologies. The choice between these two technologies must be made based on the suitability for the specific waste sludge, the resultant waste characteristics, the final waste volume, the complexity of the process, and the estimates of the costs of processing and disposal. This choice can be very difficult if there is a wide variation in waste composition. Evaluation of the immobilization technology is needed for the full range of waste compositions to determine the preferred waste form and an appropriate recipe for the waste form. Economic considerations may lead to the choice of a single robust waste formula or to a series of formulations tailored to each waste composition. SRTC efforts have been focused on developing and testing glass formulations for the vitrification of the OR tank wastes.

Vitrification is a mature technology for immobilizing radioactive wastes in a solid form. It involves combining the waste with glass formers and melting the resultant mixture at elevated temperatures (typically, 1100 to $1300^{\circ} \mathrm{C}$ ). Vitrification is considered to be the Best Demonstrated Available Technology for immobilization of high-level waste and is currently being investigated for the treatment of low-level/mixed wastes. Vitrification of the OR tank wastes offers a number of benefits. Vitrification:

- is less expensive than many of the technologies available

- offers a large volume reduction

- produces a waste form that is very durable

- is an established technology

- can be used for a wide variety of waste streams

- produces a waste form that is resistant to radiation damage

Prior to a full-scale demonstration, a glass formulation that will produce a glass that is both processable and durable must be developed. Crucible studies using simulated OR sludges and reagent grade glass-forming chemicals (or frit) were performed. Initially, scoping studies were performed to determine the chemicals necessary to form a glass. Then, tests were performed to determine the processing and product properties of the vitrified waste form. These tests included viscosity and liquidus determinations and durability tests.

This paper focuses on the results of developing glass formulations for the GAAT and MVST/BVEST sludges. These results provide the preliminary data for developing a glass formulation which will immobilize a sludge composition obtained from averaging the contents of all four tank farms (composite composition). Although blending the contents of all four tanks is not feasible, this average composition provides a basis from which to develop a glass formulation. Once a frit formulation is developed which produces a durable glass waste form at relatively high waste loadings, then a statistically designed approach will be implemented to determine the size of 
the sludge compositional window which can be adequately immobilized by the frit formulation.

\section{BACKGROUND}

A goal of this task was to develop a glass formulation that could incorporate significant quantities of the OR tank sludges. The formulation must be compatible with possible vendor melters which would process the tank sludges. This includes refractory and electrode compatibility, appropriate melt and liquidus temperatures, reasonable viscosity and adequate electrical conductivity. In addition, the final waste form must have an acceptable durability.

The waste loading within the glass is dependent upon development of a glass formulation which will produce a waste form which meets the Waste Acceptance Criteria (WAC) of the disposal site and has properties (viscosity, liquidus, and redox) compatible with vitrification processing. Increasing the waste loading will decrease the processing time, decrease the volume of waste produced, increase the radionuclide content and generally lower costs. However, higher waste loadings may also increase the melt temperatures (thus, increasing volatility) and decrease the performance of the waste form. Therefore, a balance of all variables must be made to ensure an optimum glass formulation is developed.

Calculations were performed to determine the amount of glass that would be produced at various waste loadings, assuming approximately one million kilograms of waste at OR. The calculations also assumed a glass density of $2.5 \mathrm{~g} / \mathrm{cc}$. The results of the calculations are provided in Table 1 .

\section{Table 1. Amount of Glass and Number ofiCanisters Produced} as a Function of Waste Loading in the Glass

\begin{tabular}{|c||c|c|}
\hline $\begin{array}{c}\text { Waste Loading } \\
\text { (wt\%) }\end{array}$ & $\begin{array}{c}\text { Glass } \\
\text { Produced (kg) }\end{array}$ & $\begin{array}{c}\text { Number of } \\
\text { Canisters }\end{array}$ \\
\hline \hline 10 & $5.8 \mathrm{E}+6$ & 3450 \\
\hline 20 & $3.0 \mathrm{E}+6$ & 1724 \\
\hline 30 & $1.9 \mathrm{E}+6$ & 1150 \\
\hline 40 & $1.5 \mathrm{E}+6$ & 864 \\
\hline 50 & $1.2 \mathrm{E}+6$ & 690 \\
\hline
\end{tabular}

The number of canisters of glass produced depends significantly on the waste loading. Table 1 presents the number of canisters produced as a function of the waste loading. These canisters are the largest canisters allowed by the WIPP for disposal ( $10 \mathrm{ft}$ long and $2 \mathrm{ft}$. in diameter) and typicaliy contain an average of approximately $1700 \mathrm{~kg}$ of glass. The processing time to produce the canisters will depend on the size and throughput of the selected melter, along with the attainment rate. 
The importance of maximizing the waste loading is evident from Table 1. Increasing the loading from $30 \mathrm{wt} \%$ to $40 \mathrm{wt} \%$ would decrease the glass produced. However, in order for the higher waste loadings and corresponding savings to be realized, the disposal site would have to be able to handle higher radiation doses.

The glass durability is measured using the Product Consistency Test (PCTT). The PCT is a crushed glass leach test that measures the releases of several elements from the glass. The test is performed in $90^{\circ} \mathrm{C}$ deionized water for seven days. The PCT creates leaching conditions which are more aggressive than those for the Toxicity Characteristic Leaching Procedure (TCLP) to provide information about glass durability under accelerated (worst case) leaching conditions. In addition, the PCT is a better indicator of the glass durability because it is a glass-dominated rather than a solution-dominated durability test. The results of the PCT test for each glass are compared to the Environmental Assessment (EA) glasis to determine acceptability. The acceptance criteria for high-level waste glasses states that the glass produced must be more durable than the EA glass. Since there is currently no criteria for low-level waste, the EA glass benchmark values will be used.

\section{CHEMICAL COMPOSITION OF THE COMPOSITE SLUDGE}

The chemical composition of the composite sludge was obtained by calculating a weighted average of the contents of the four tank farms. The major elemental composition of each tank farm, along with the overall composite sludge is provided in Table 2 . The amount of sludge and chemical composition of the sludge in each tank farm was estimated as follows:

MVST: The MVST tank farm consists of eight 50,000 gallon tanks (Building 7830 ) identified as W-24 through W-31. Two of the tanks, W-29 and W-30, have been modified to serve as feed tanks. Therefore, these two tanks have been excluded from defining the average MVST chemical composition.

BVEST: The BVEST tank farm consists of five 50,000 gallon tanks identified as W-21, W-22, W-23, C-1, and C-2. Tanks C-1 and C-2 were not sampled and consequently their contents have not been included in the determination of blended average of the BVEST.

GAAT: The tanks included for defining the amount and average chemical composition of the GAAT sludge waste are W-3 through W-10.

OHF: OHF tank farm consists of five tanks, all of which were included in the calculation of the average chemical composition and the amount of sludge.

Composite: The overall composite average was obtained by weighted averaging of the $5 \mathrm{OHF}, 8 \mathrm{GAAT}$, and $9 \mathrm{MVST} / \mathrm{BVEST}$ tanks. This data was received from Oak Ridge in December, 1996 and was used as the basis for the definition of the overall composite composition. 
Table 2. Composition of major components in each of the four OR Tank Farms, along with the statistically weighted average (Composite).

\begin{tabular}{|c||c|c|c|c|c|}
\hline Species & MVST & BVEST & GAAT & OHF & Composite \\
\hline \hline $\mathrm{Al}$ & 1.4 & 0.6 & 9.3 & 7.1 & 2.5 \\
\hline $\mathrm{Ca}$ & 11.9 & 18.5 & 7.2 & 14.4 & 12.2 \\
\hline $\mathrm{Fe}$ & 0.5 & 0.8 & 5.4 & 2.6 & 1.3 \\
\hline $\mathrm{K}$ & 3.1 & 4.0 & 2.4 & 1.6 & 3.1 \\
\hline $\mathrm{Mg}$ & 2.2 & 3.7 & 1.7 & 1.4 & 2.3 \\
\hline $\mathrm{Na}$ & 16.8 & 16.0 & 19.0 & 4.8 & 16.2 \\
\hline $\mathrm{P}$ & 0.5 & 3.1 & 0.6 & 3.5 & 1.5 \\
\hline $\mathrm{Pb}$ & 0.1 & 0.2 & 0.7 & 0.2 & 0.2 \\
\hline $\mathrm{Si}$ & 1.6 & 0.5 & 1.9 & 6.8 & 1.7 \\
\hline $\mathrm{Th}$ & 1.5 & 4.4 & 5.6 & 47.1 & 3.7 \\
\hline $\mathrm{U}$ & 2.5 & 9.0 & 30.9 & 5.0 & 9.6 \\
\hline & & & & & \\
\hline Chloride & 0.7 & 0.7 & 0.3 & 0.3 & 0.6 \\
\hline Fluoride & 0.0 & 0.0 & 1.3 & 0.1 & 0.2 \\
\hline Nitrate & 55.3 & 34.4 & 8.1 & 2.7 & 41.6 \\
\hline Nitrite & 0.8 & 1.1 & 0.0 & 1.1 & 1.1 \\
\hline Sulfate & 0.4 & 1.3 & 3.1 & 0.7 & 0.9 \\
\hline
\end{tabular}

\section{RESULTS AND DISCUSSION}

Using ORNL information on the characterization of the tank waste sludges, SRTC has been performing extensive bench-scale vitrification studies using simulants. Several glass systems have been tested to ensure the optimum glass composition is determined. This optimum composition will balance waste loading, melt temperature, waste form performance and disposal requirements. By optimizing the glass composition, a cost savings can be realized during vitrification of the waste. The preferred glass formulation will be selected from the bench-scale studies and recommended to ORNL for further testing with samples of actual OR waste tank sludges.

Scoping studies were performed first on the GAAT sludges. These tanks were originally planned to be immobilized separately from the sludges in the other tank farms on a more aggressive closure schedule. Therefore, work concentrated on the individual tanks in the order of scheduled closure. Tanks W3 and W4 were the first tanks scheduled to be dispositioned. The analysis of the sludge in these tanks showed approximately $79 \mathrm{wt} \%$ uranium, $11 \mathrm{wt} \%$ sodium, $5 \mathrm{wt} \%$ aluminum and small amounts of phosphate, sulfate, nitrate, calcium, and iron. A simulant was made based on the analyzed sludge composition using depleted uranium dioxide and the appropriate reagent grade chemicals. 
Efforts were then made to find a frit (or glass forming chemicals) that could be added to the Tanks W3 and W4 simulant to produce a durable waste form with a high waste loading. The waste simulant and the frit chemicals were combined and placed in alumina crucibles. The samples were vitrified at $1100^{\circ} \mathrm{C}$ for four hours. The crucibles were then removed and allowed to air cool to room temperature. The glass was broken out of the crucible and ground for analysis.

The glass samples were analyzed to determine the chemical composition.

Each sample was dissolved by two separate dissolution methods according to approved procedures. The dissolutions were analyzed by Atomic Absorption (AA) spectrometry and Inductively Coupled Plasma Emission Spectroscopy (ICP-ES). The results of these analyses are provided in Table 3 for the Tanks W3 and W4 glasses. Different frit compositions were used for the different waste loadings. X-Ray Diffraction (XRD) results indicated that these glasses did not contain significant crystallization.

Table 3 - Chemical Compositions (in wt\% oxides) of Borosilicate Glass using Tanks W3 \& W4 Surrogate

\begin{tabular}{|c||c|c|c|c|}
\hline Oxide & 10 wt\% & 20 wt\% & 30 wt\% & 40 wt\% \\
\hline \hline $\mathrm{Al}_{2} \mathrm{O}_{3}$ & 7.74 & 5.63 & 2.70 & 4.21 \\
\hline $\mathrm{B}_{2} 03$ & 5.68 & 5.83 & 11.12 & 9.18 \\
\hline $\mathrm{CaO}$ & 0.40 & 0.43 & 0.19 & 0.26 \\
\hline $\mathrm{Cr}_{2} \mathrm{O}_{3}$ & 0.18 & 0.16 & 0.19 & 0.17 \\
\hline $\mathrm{Fe}_{2} 0_{3}$ & 3.86 & 1.56 & 0.74 & 0.62 \\
\hline $\mathrm{Li}_{2} \mathrm{O}$ & 12.52 & 8.50 & 4.18 & 4.31 \\
\hline $\mathrm{MgO}$ & 0.27 & 0.27 & 1.44 & 1.21 \\
\hline $\mathrm{Na}_{2} \mathrm{O}$ & 6.25 & 9.55 & 7.95 & 9.14 \\
\hline $\mathrm{SiO}_{2}$ & 53.19 & 50.11 & 45.88 & 37.87 \\
\hline $\mathrm{ThO}_{2}$ & 0.23 & 0.57 & 0.93 & 1.26 \\
\hline $\mathrm{TiO}_{2}$ & 3.32 & 2.48 & 1.51 & 1.23 \\
\hline $\mathrm{UO}_{3}$ & 7.21 & 15.62 & 22.83 & 31.24 \\
\hline
\end{tabular}

The PCT was performed on all of the glass samples. Samples are run in triplicate and each 7-day test includes the appropriate blanks and standards. The results of the standards and blanks indicated that the tests were acceptable. The average PCT releases for several elements were measured. These values were used along with the composition of the glass to calculate the average normalized release for boron, sodium, and lithium. The leachate $\mathrm{pH}$ was measured as part of the PCT protocol and provides a secondary indication of glass durability.

The normalized elemental releases reported in Table 4 indicate that the glasses made with surrogate Tanks W3 and W4 waste met the HLW acceptance criteria, which states that the glass produced must be at least two standard deviations better than the Environmental Assessment (EA) glass. 
Table 4 - Normalized PCT Results (in $\mathrm{g} / \mathrm{L}$ ) and Standard Deviations for Borosilicate Glass using GAAT Tanks W3 and W4

\begin{tabular}{|c||c|c|c|c|}
\hline Sample ID & $\mathrm{B}$ & $\mathrm{Na}$ & $\mathrm{Li}$ & $\mathrm{pH}$ \\
\hline \hline $10 \mathrm{wt} \%$ & $1.8 \pm 0.3$ & $1.4 \pm 0.7$ & $2.2 \pm 1.7$ & $11.7 \cdot$. \\
\hline $20 \mathrm{wt} \%$ & $2.9 \pm 0.4$ & $2.2 \pm 1.1$ & $3.1 \pm 1.2$ & 11.5. \\
\hline $30 \mathrm{wt} \%$ & $7.9 \pm 2.9$ & $4.2 \pm 2.8$ & $7.2 \pm 1.4$ & 10.0 \\
\hline $40 \mathrm{wt} \%$ & $3.4 \pm 1.0$ & $1.7 \pm 0.5$ & $3.5 \pm 0.3$ & 10.4 \\
\hline & & & & \\
\hline EA & 16.7 & 13.3 & 9.6 & 11.9 \\
\hline
\end{tabular}

Crucible scoping studies have also been performed with a simulant derived from a statistical combination of the waste in the MVST and BVEST. This combination of the MVST/BVEST waste had higher concentrations of calcium than the GAAT waste, so glasses in the soda-lime silica family were tested. Several frits were tested at various MVST/BVEST waste loadings. Table 5 provides the chemical composition of a few of the higher waste loading glasses. The corresponding PCT results are provided in Table 6. Since the MVST/BVEST glasses are soda-lime-silica glasses, only the sodium and silicon PCT results are presented in Table 6. These results indicate that durable glass can be produced with the MVST/BVEST waste.

Table 5 - Major Chemical Compositions (in wt\% oxides) of Soda-Lime-Silica Glass using MVST/BVEST Surrogate

\begin{tabular}{|c||c|c|c|}
\hline Oxide & $40 \mathrm{wt} \%$ & $45 \mathrm{wt} \%$ & $50 \mathrm{wt} \%$ \\
\hline \hline $\mathrm{Al}_{2} \mathrm{O}_{3}$ & 3.98 & 9.53 & 3.87 \\
\hline $\mathrm{CaO}$ & 13.08 & 16.98 & 12.07 \\
\hline $\mathrm{Cr}_{2} \mathrm{O}_{3}$ & 0.01 & 0.18 & 0.20 \\
\hline $\mathrm{Fe}_{2} 0_{3}$ & 0.26 & 0.97 & 1.04 \\
\hline $\mathrm{K}_{2} \mathrm{O}$ & 1.57 & 1.61 & 0.33 \\
\hline $\mathrm{MgO}$ & 1.25 & 1.64 & 1.72 \\
\hline $\mathrm{Na}_{2} \mathrm{O}$ & 8.78 & 9.55 & 19.65 \\
\hline $\mathrm{SiO}_{2}$ & 51.07 & 47.23 & 57.26 \\
\hline $\mathrm{ThO}_{2}$ & 0.19 & 0.23 & 0.23 \\
\hline $\mathrm{UO}_{3}$ & 3.58 & 3.70 & 3.73 \\
\hline
\end{tabular}

Table 6 - Normalized PCT Results (in $\mathrm{g} / \mathrm{L}$ ) and Standard Deviations for Soda-Lime-Silica Glass using MVST/BVEST Surrogate

\begin{tabular}{|c||c|c|c|}
\hline Sample ID & $\mathrm{Si}$ & $\mathrm{Na}$ & $\mathrm{pH}$ \\
\hline \hline 40 wt\% & $0.11 \pm 0.3$ & $6.86 \pm 0.2$ & 10.8 \\
\hline 45 wt\% & $0.08 \pm 0.2$ & $0.61 \pm 0.6$ & 10.8 \\
\hline 50 wt\% & $0.13 \pm 0.1$ & $6.34 \pm 0.7$ & 10.4 \\
\hline & & & \\
\hline EA & 3.9 & 13.3 & 11.9 \\
\hline
\end{tabular}




\section{CONCLUSIONS AND PATH FORWARD}

The results of these tests indicate that sufficient GAAT or MVST/BVEST waste loadings can be obtained in glass to significantly reduce the waste volume. The results of the MVST/BVEST will provide the basis for the composite formulation efforts because the majority of the waste in the OR tank farms comes from the MVST and the BVEST. Therefore, the composition of the composite sludge is very similar to the composition of the MVST/BVEST combination.

The glasses developed during the MVST/BVEST scoping studies were used to develop a set of experiments designed to determine an optimum frit composition. Once a frit has been developed for the average composite sludge, the composition of the sludge will be varied through a statistically designed experiment to determine the robustness of the frit.

\section{REFERENCES}

ASTM Procedure, C-1286-94, "Determining Chemical Durability of Nuclear Waste Glasses: The Product Consistency Test (PCT)".

U. S. Department of Energy, "Environmental Assessment Waste Form Selection for SRP High-Level Waste", USDOE Report DOE-EA-0179, July, 1982.

C. M. Jantzen, N. E. Bibler, D. C. Beam, C. L. Crawford, and M. A. Pickett, "Characterization of the Defense Waste Processing Facility (DWPF)

Environmental Assessment (EA) Glass Standard Reference Material (U)", WSRC-TR-92-346, Rev. 1, June, 1993. 